\title{
HOURLY PRECIPITATION PATTERNS IN A BRAZILIAN TROPICAL CITY
}

\author{
SANTOS, Luiz Octavio Fabrício dos - luizoctavio@fisica.ufmt.br \\ Universidade Federal de Mato Grosso / UFMT \\ MACHADO, Nadja Gomes - nadja.machado@blv.ifmt.edu.br \\ Instituto Federal do Mato Grosso / IFMT
}
QUERINO, Carlos Alexandre Santos - carlosquerino@ufam.edu.br Universidade Federal do Amazonas / UFAM

PEDREIRA JUNIOR, Altemar Lopes - altemarjunior@fisica.ufmt.br Universidade Federal de Mato Grosso / UFMT

IVO, Israel Oliveira - israel@fisica.ufmt.br Universidade Federal de Mato Grosso / UFMT
LOTUFO NETO, Névio - neviolotufo@fisica.ufmt.br Universidade Federal de Mato Grosso / UFMT
BIUDES, Marcelo Sacardi - marcelo@fisica.ufmt.br Universidade Federal de Mato Grosso / UFMT

\begin{abstract}
The research on precipitation is related to analysis of its spatiotemporal variability using daily, monthly and annual data. However, there is a scarcity in the availability of information on how this variable is distributed over the hours of the day. Thus, the objective of this study was to analyze the intensity and hourly patterns of precipitation in Cuiabá in the State of Mato Grosso. Precipitation data were collected at the Cuiabá weather station of the National Institute of Meteorology from 2003 to 2018. The relative frequency of hourly precipitation was analyzed by the Spiegel method. The relative frequency of precipitation in wet season was high in the afternoon from 16:00 $\mathrm{h}$ $(6.2 \%)$ to $17: 00 \mathrm{~h}(5.9 \%)$ and low in the morning from $10: 00(3.0 \%)$ to $11: 00(2.8 \%)$. The relative frequency of precipitation during the dry season was high at 05:00 $\mathrm{h}(5.0 \%)$ and $17: 00 \mathrm{~h}(5.4 \%)$ and low from $12: 00 \mathrm{~h}(2.6 \%)$ and $13: 00 \mathrm{~h}(2.2 \%)$. In general, the intensity of precipitation in the region was predominantly weak, followed by moderate, strong and very strong. The precipitation events in Cuiabá generally occur in the late afternoon, resulting from convective activity in the region.
\end{abstract}

KEYWORDS: climatology, relative frequency, rainfall intensity

\section{PADRÕES DE PRECIPITAÇÃO HORÁRIA EM UMA CIDADE TROPICAL BRASILEIRA}

RESUMO: As pesquisas sobre precipitação estão relacionadas a análises de sua variabilidade espaço-temporal utilizando dados diários, mensais e anuais. No entanto, há uma escassez na disponibilidade de informações sobre como esta variável se distribui ao longo das horas do dia. Desta forma, o objetivo deste estudo foi analisar a intensidade e a variabilidade horária da precipitação na cidade de Cuiabá no Estado de Mato Grosso. Os dados de precipitação foram coletados na estação meteorológica de Cuiabá do Instituto Nacional de Meteorologia de 2003 a 2018. A frequência relativa horária de precipitação foi analisada pelo método de Spiegel. A frequência relativa da precipitação no período chuvoso foi maior à tarde das $16: 00 \mathrm{~h}(6.2 \%)$ às $17: 00 \mathrm{~h}(5.9 \%)$ e a menor na manhã das $10: 00 \mathrm{~h}(3.0 \%)$ às $11: 00 \mathrm{~h}(2.8 \%)$. A frequência relativa da precipitação durante 0 período seco foi maior às $05: 00 \mathrm{~h}(5.0 \%)$ e às $17: 00 \mathrm{~h}(5.4 \%)$ e menor de $12: 00 \mathrm{~h}$ $(2.6 \%)$ a $13: 00 \mathrm{~h}(2.2 \%)$. Em geral, a intensidade da precipitação na região foi de predominantemente fraca, seguida de moderada, forte e muito forte. Os eventos de 
precipitação em Cuiabá ocorrem geralmente no final da tarde, resultante de atividade convectiva na região

PALAVRAS-ChAVE: climatologia urbana, frequência relativa de chuva, intensidade de chuva.

\section{INTRODUCTION}

Cuiabá is the capital of the State of Mato Grosso and is in a transition region between the Cerrado and Pantanal biomes. Its economy is based on agribusiness (agriculture and livestock) (MACHADO et al., 2015b), which is affected by the of climate variables pattern. The variability of precipitation (Ppt) is a factor of great importance for the development of the region's economy, and the excess or lack of Ppt can cause large-scale damage to the state economy (DALLACORT et al., 2011).

Ppt is defined as the deposition of all of forms of water particles from the atmosphere (MARENGO et al., 2001) and it is considered as a determinant agent of environmental dynamics (GIRÃO and CORREA, 2004; SANTOS et al., 2019). It acts as a major factor in the hydrological cycle, directly driving the physical, chemical and biological processes within the soil-plant-atmosphere system (FU et al., 2016). Thus, Ppt presents itself as a meteorological variable of great spatiotemporal variability (MACHADO et al., 2015a).

Most research on $\mathrm{Ppt}$ is related to analyzes of its spatiotemporal variability using daily, monthly and annual data (TRENBERTH and ZHANG, 2017). However, the information of hourly pattern of precipitation is scarce (PEDREIRA JUNIOR et al., 2018). The intermittent nature of precipitation highlights the need to quantify characteristics on time scales such as frequency, intensity and duration (TRENBERTH et al., 2017).

Studies of hourly Ppt pattern can provide important information to researchers, such as possible trends throughout the day, which are not observed in daily, monthly, or annual scale measurements (BROWN et al., 2018). The use of these information provides a better local view of the complex variability of Ppt (BURAUSKAITE-HARJU et al., 2012), and to measure the impacts on the soil, agricultural planning, runoff, degradation and water availability (WESTRA et al., 2013; JOSHI et al., 2019).

The knowledge of the intensity of Ppt events pattern is essential, not only in natural areas but also in urban areas (BECK et al., 2015). It supports studies on how the Ppt can affect urban safety and well-being, especially in risk areas (GAO et al., 2016). This information can be used by decision making regarding drainage plans, flood prediction and environmental disasters resulting from precipitation accumulation, what can minimize economic and social impacts (SENTELHAS et al., 1998; CECÍLIO et al., 2009).

Recent studies in the Southern Amazon (PEDREIRA JUNIOR et al., 2018), Northern Rondônia (SANTOS NETO et al., 2014) and Southern United States (BROWN et al., 2018) have collaborated to better understand the hourly relative frequency and intensity of precipitation in urban and rural environment. In this context, studies of this nature are of great importance for the metropolitan region of Cuiabá. Therefore, the objective of this study was to analyze the hourly relative frequency and intensity of precipitation in Cuiabá, Mato Grosso. 


\section{MATERIALS AND METHODS}

\section{STUDY AREA}

Cuiabá (Figure 1) is situated in the South-Central portion of Mato Grosso $\left(15^{\circ} 35^{\prime} \mathrm{S}, 56^{\circ} 07^{\prime} \mathrm{W}\right.$ and $151 \mathrm{~m}$ of altitude). The region's climate is Aw (hot and humid) according to the Köppen classification, with wet season from October to April and dry season from May to September (CHIARANDA et al., 2012). The average annual precipitation is $1335 \mathrm{~mm}$ year-1 (MACHADO et al., 2015b).

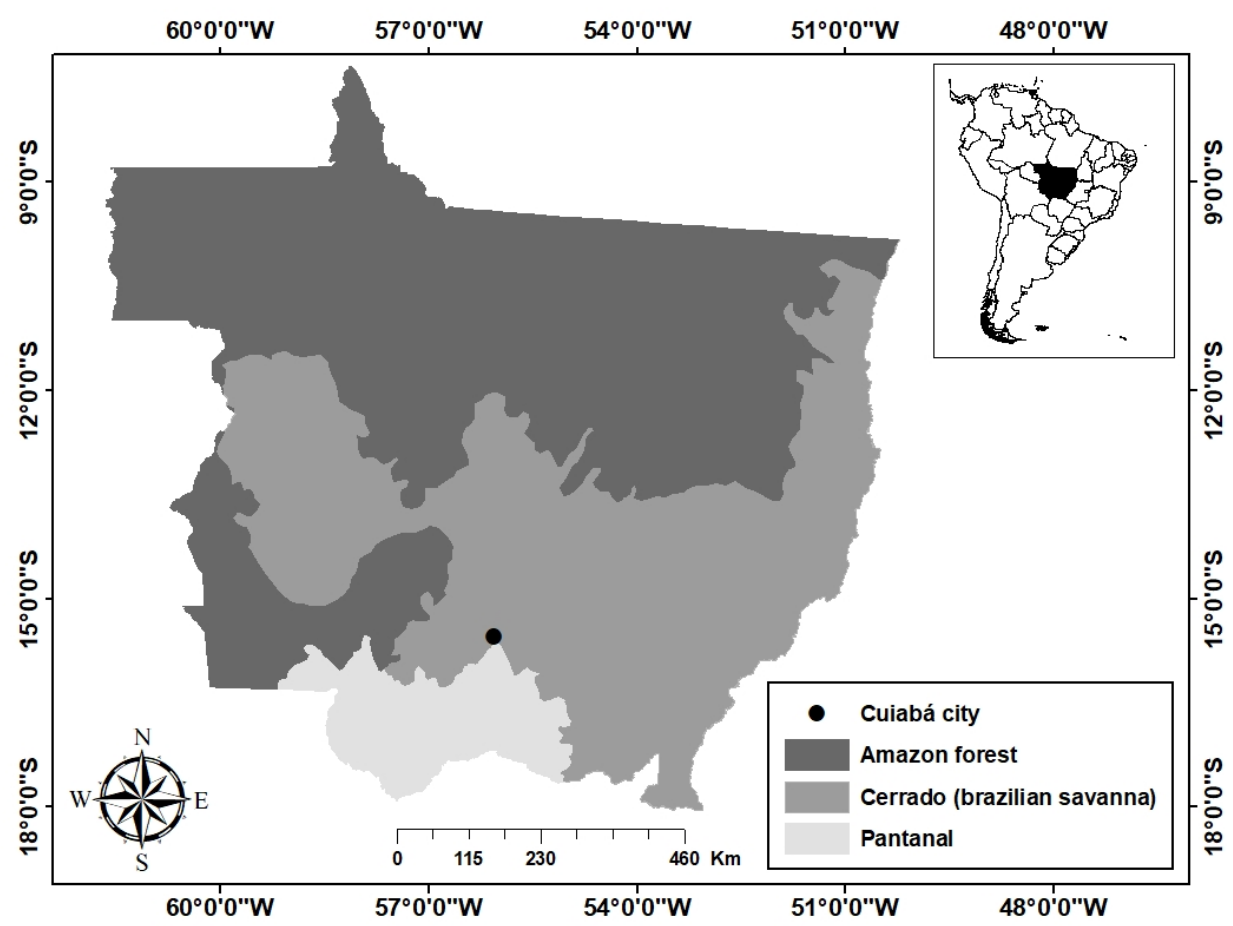

Figure 1 - Location of the automatic weather station of National Meteorological Institute (INMET) in Cuiabá, Mato Grosso, Brazil.

\section{DATA}

Ppt were collected from 2003 to 2018 (16 years) by a rain gauge (QMR102, Vaisala) installed in the automatic weather station of Cuiabá (15.55 ${ }^{\circ}$ $\mathrm{S}, 56.06^{\circ} \mathrm{W}$ and $242 \mathrm{~m}$ ) from the National Meteorological Institute (INMET). The Climatological Normal (NC) used for comparison with the studied period was from 1961-1990 provided by INMET.

\section{DATA PROCESSING}

The Relative Frequency (RF\%) of Ppt was determined by the method proposed by Spiegel (1972) (Equation 1).

$R F(\%)=\frac{F(h)}{F(24)} \times 100$ 
where RF (\%) is the Relative Frequency of Ppt, $F(h)$ the amount of Ppt events that occurred at each time and $F(24)$ is the 24-hour Ppt occurrence count over the entire period analyzed. Only Ppt events $\geq 0.2 \mathrm{~mm} \mathrm{~h}^{-1}$ were the events considered in the analyzes.

Data were organized by hydrological periods (wet and dry) and seasons (summer, fall, winter and spring). The Rain Intensity (RI) was classified according to Minuzzi and Sediyama (2004) as recommended by the World Meteorological Organization (WMO) (Table 1).

Table 1 - Rain Intensity (RI) classification (MINUZZI and SEDIYAMA, 2004).

\begin{tabular}{cc}
\hline Categories & $\mathbf{R I}\left(\mathbf{m m ~ h}^{\mathbf{- 1}}\right)$ \\
\hline Weak rain & $1.1<\mathrm{RI} \leq 5.0$ \\
Moderate rain & $5.1<\mathrm{RI} \leq 25.0$ \\
Strong rain & $25.1<\mathrm{RI} \leq 50.0$ \\
Very Strong rain & $\mathrm{RI} \geq 50.1$ \\
\hline
\end{tabular}

\section{STATISTICAL ANALYSIS}

The average of daily totals ( $X$-day), means of monthly totals ( $X$-month) and maximum (Max) and minimum (Min) values were used to verify and summarize the pattern of the Ppt time series. Data asymmetry (As) was evaluated by Equation 2.

As $=\frac{n}{(n-1)(n-2)} \sum\left[\frac{X_{i}-\bar{X}}{D P}\right]^{3}$

where $\mathrm{n}$ is the number of observations, $\mathrm{X}_{\mathrm{i}}$ is the measured Ppt value and $\bar{X}$ is the average of the Ppt values.

Measurement of data dispersion within a sample with respect to the mean was performed by Standard Deviation (SD) (Equation 3).

$S D=\sqrt{\frac{\sum_{i=1}^{n}\left(X_{i}-\bar{X}\right)^{2}}{n-1}}$

The variation of the sample mean in relation to the series mean was made by the Standard Error (SE) (Equation 4).

$\mathrm{SE}=\frac{S D}{\sqrt{\mathrm{n}}}$

The dispersion measure to characterize the degree of flatness of the distribution curve of a set of measurements was given by Kurtosis (K) (Equation $5)$.

$\mathrm{K}=\frac{1}{\mathrm{n}} \sum\left[\frac{\mathrm{Xi}-\overline{\mathrm{X}}}{S D}\right]^{4}-3$

Median (MD) was used to find the value that occupies the central position and to look for trends in the data series (Equation 6). 
$\begin{array}{ll}M D=\frac{(n+1)}{2}, & \text { if } n \text { is odd } \\ M D=\frac{\left(\frac{n}{2}\right)^{2}+\left(\frac{n}{2}+1\right)}{2}, & \text { if } n \text { is even }\end{array}$

The data dispersion measure was calculated by the variance (Var) (Equation 7), which indicates how far their values are from the expected value (mean).

$\operatorname{Var}=\frac{\sum_{i=1}^{n}(X i-\bar{X})^{2}}{n-1}$

\section{RESULTS AND DISCUSSIONS}

The annual average of Ppt during the study period was $1401 \mathrm{~mm} \mathrm{y}^{-1}$, with maximum in 2009 (1651.4 $\mathrm{mm} \mathrm{y}^{-1}$ ) and minimum in 2005 (1002.8 $\mathrm{mm} \mathrm{y}^{-}$ $\left.{ }^{1}\right)$. There were anomalies on Ppt when comparing to the Climatological Normal (CN) (1961-1990) of INMET. The annual Ppt average was 4.4\% higher than CN. The wet season was $5.8 \%$ longer than the wet season of $\mathrm{CN}$ and the dry season was $6.8 \%$ shorter than the dry season of CN (Figure 2). These differences are consequences of irregularity in several atmospheric systems operating in the region (MARCUZZO et al., 2012).

The interannual variability of Ppt in the region may be correlated to large-scale phenomena such as El Ñino Southern Oscillation (ENSO). The action of this phenomenon induces changes in the patterns of atmospheric circulation, caused due to the cooling or abnormal heating of the waters of the Tropical Pacific Ocean and, consequently, influences the rainfall in tropical and midlatitude regions (GRIMM et al., 2003; 2009).

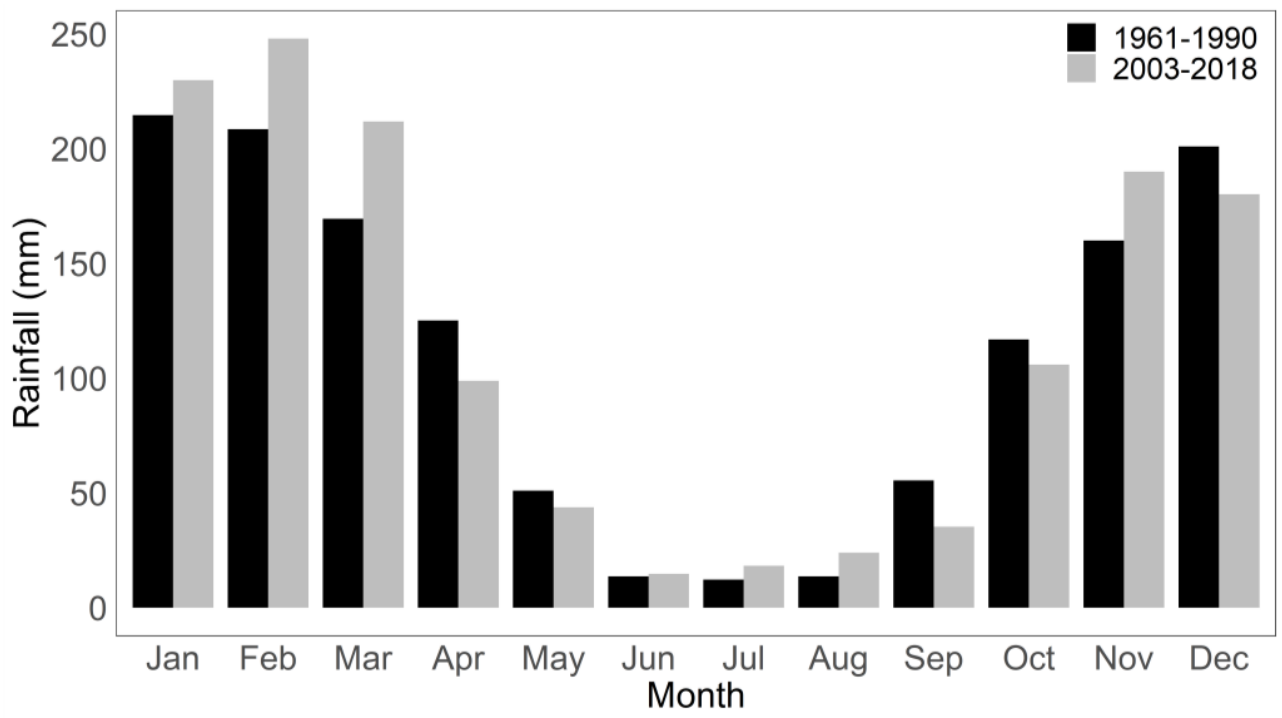

Figure 2 - Monthly precipitation mean from 2003 to 2018 and Climatological Normal (CN) from 1961 to 1990 provided by the National Institute of Meteorology (INMET) in Cuiabá, Mato Grosso, Brazil. 
Ppt data had positive asymmetry, which indicates that most Ppt events had low intensity (Table 2). The highest SEs occurred in the dry season and the highest SDs in the wet months (January, March and October). Kurtosis was positive in all months, which indicate regularity of Ppt events. The largest dispersion values between the data (variance) were occurred in October. This month is the winter-spring transition period, where there is a resumption of strong convective activities in the region (MARCUZZO et al., 2011).

Table 2 - Descriptive statistics of daily average precipitation data from 2003 to 2018 in Cuiabá, Mato Grosso State, Brazil. Climatological Normal (CN); Monthly Average $\left(\bar{X}_{\text {month }}\right)$; Daily Average $\left(\bar{X}_{\text {day }}\right)$; Asymmetry (As); Standard Deviation (SD); Standard Error (SE); Kurtosis (K); Median (MD); Variance (Var); Maximum (Max); Minimum (Min).

\begin{tabular}{lccccccccccc}
\hline Month & CN & $\overline{\mathbf{X}}_{\text {month }}$ & $\overline{\mathbf{X}}_{\text {day }}$ & As & SD & SE & K & MD & Var & Max & Min \\
\hline Jan & 247.5 & 229.9 & 11.7 & 2.9 & 16.2 & 0.9 & 11.7 & 5.4 & 261.3 & 124.3 & 0.2 \\
Feb & 220.4 & 248.0 & 13.7 & 2.6 & 17.5 & 1.0 & 8.7 & 7.0 & 307.7 & 118.9 & 0.2 \\
Mar & 217.5 & 211.9 & 12.8 & 2.8 & 18.5 & 1.1 & 9.6 & 5.1 & 342.6 & 127.9 & 0.2 \\
Apr & 117.8 & 98.9 & 9.3 & 2.3 & 11.4 & 0.9 & 6.0 & 4.6 & 131.1 & 63.4 & 0.2 \\
May & 50.4 & 43.8 & 10.6 & 3.2 & 15.6 & 1.9 & 12.4 & 4.4 & 243.4 & 87.3 & 0.2 \\
Jun & 19.4 & 14.8 & 5.9 & 1.8 & 7.5 & 1.3 & 2.9 & 2.2 & 56.9 & 29.8 & 0.2 \\
Jul & 16.0 & 18.3 & 7.4 & 1.6 & 10.5 & 1.9 & 1.7 & 1.7 & 109.9 & 39.9 & 0.2 \\
Aug & 22.1 & 24.0 & 8.6 & 4.1 & 15.1 & 2.9 & 18.9 & 5.2 & 228.0 & 79.2 & 0.2 \\
Sep & 51.3 & 35.3 & 8.0 & 3.8 & 13.0 & 1.5 & 18.8 & 3.2 & 168.2 & 86.0 & 0.2 \\
Oct & 114 & 106.0 & 11.3 & 3.2 & 18.3 & 1.5 & 12.0 & 5.1 & 333.9 & 118.2 & 0.2 \\
Nov & 172.9 & 190.0 & 14.7 & 1.8 & 17.1 & 1.2 & 3.6 & 7.3 & 293.8 & 85.4 & 0.2 \\
Dec & 205.2 & 180.3 & 10.8 & 2.2 & 14.0 & 0.9 & 5.3 & 5.4 & 197.4 & 73.7 & 0.2 \\
\hline
\end{tabular}

There were on average 112 wet days and 242 dry days (Figure 3A). The highest number of wet days (164 days) occurred in 2008 and the highest number of dry days (276 days) occurred in 2005 (76.6\% of the year). The high number of wet days in 2008 was due to the occurrence of a strong La Niña event during wet months in the region. On the other hand, an El Niño event minimized the frequency of Ppt events in the wet season of 2005 in the region. On average, the wettest months were from December to February, and the driest months were from June to August (Figure 3B). 

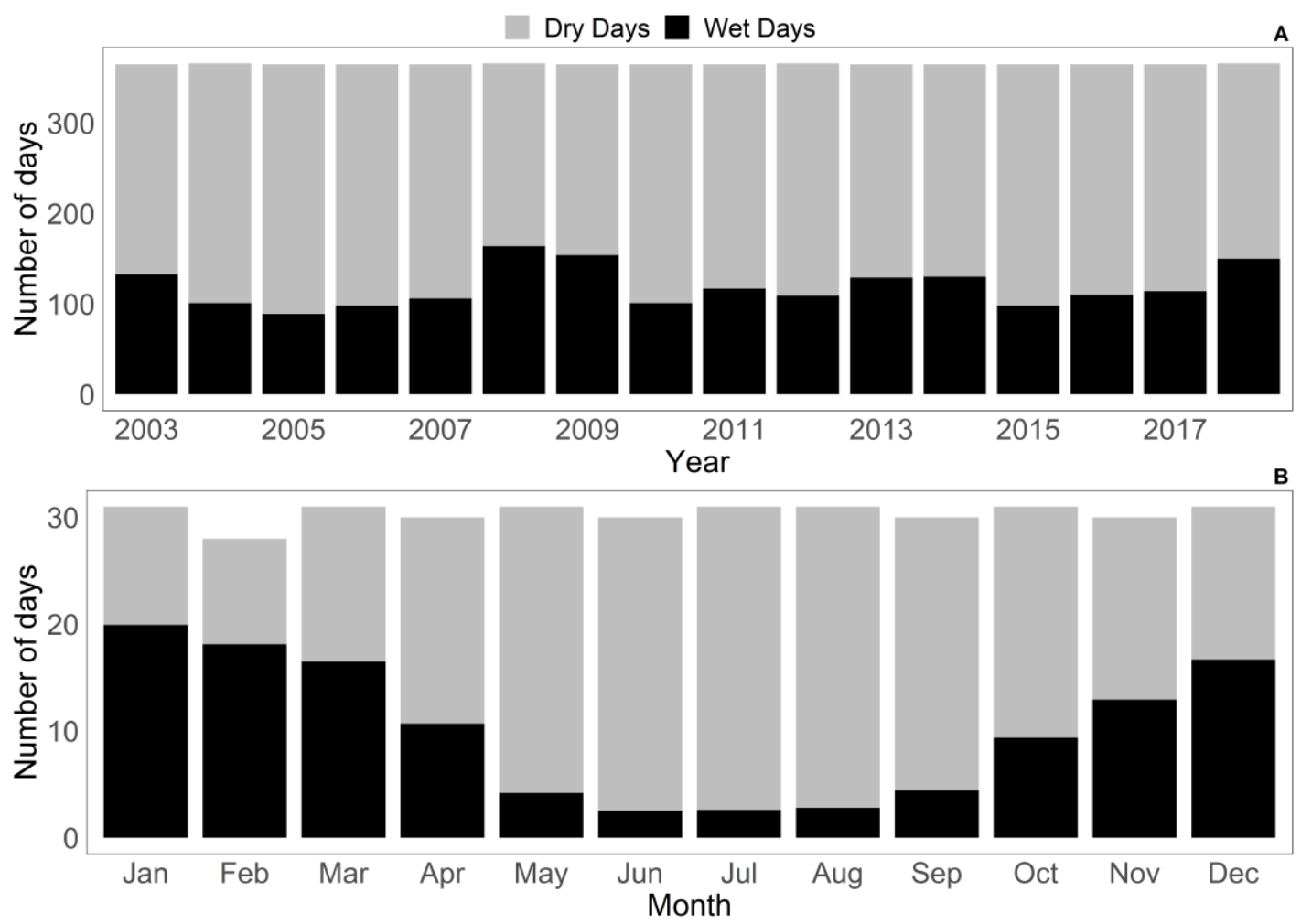

Figure 3 - Interannual (A) and monthly (B) number of dry and wet days in Cuiabá, Mato Grosso, Brazil.

The higher RF of Ppt in the wet season occurred in the afternoon from $16: 00 \mathrm{~h}(6.2 \%)$ to $17: 00 \mathrm{~h}(5.9 \%)$, and the lower from $10: 00 \mathrm{~h}(3.0 \%)$ to $11: 00 \mathrm{~h}(2.8 \%)$ (Figure 4$)$. The occurrence of Ppt events in the afternoon during the wet season is due to the interaction between meteorological systems with tropical and extratropical characteristics and the equatorial fronts of the Amazon, North and Northeast Instabilities, North and Northwest Instabilities and mainly the South Atlantic Convergence Zone (SACZ) and the Bolivian High (BH) (RAMOS et al., 2017). Those systems act in combination of the moisture transport and local convection (ALVES, 2009; QUERINO et al., 2017).

$\mathrm{BH}$ contributes significantly to the occurrence of Ppt in the region (SILVA et al., 2008). It is an anticyclone at high atmospheric levels resulting from the marked release of latent heat associated with intense convection in the Bolivian highland region (NOBRE et al., 2009). SACZ is also one of the most important synoptic systems that cause Ppt in the region, and may lead to high rainfall (MACHADO et al., 2015b). It is defined as a band of cloudiness and moisture convergence that extends from the Amazon to the southeast of the country with a semi-stationary character, causing wet days (SILVA et al., 2019).

The higher RF of Ppt in the dry season occurred in at 5:00 $\mathrm{h}(5.0 \%)$ and in the afternoon from $17: 00 \mathrm{~h}(5.4 \%)$ to $18: 00 \mathrm{~h}(5.0 \%)$, and the lower at noon from $12: 00 \mathrm{~h}(2.6 \%)$ to $13: 00 \mathrm{~h}(2.2 \%)$ and at night $22: 00 \mathrm{~h}(3.1 \%)$ (Figure 4$)$. The Ppt during the dry season is also related to convective activity and frontal systems (PINTO et al., 2009). During this season, the patterns of atmospheric circulation is changed, in which the air movements induce the rise of the Atlantic Tropical Anticyclone (high pressure) to the center of the South American 
continent, reaching Mato Grosso with maximum intensity from July to September. These movements cause changes in the thermodynamic properties of air and decrease the amount of Ppt events (MARCUZZO et al., 2011).

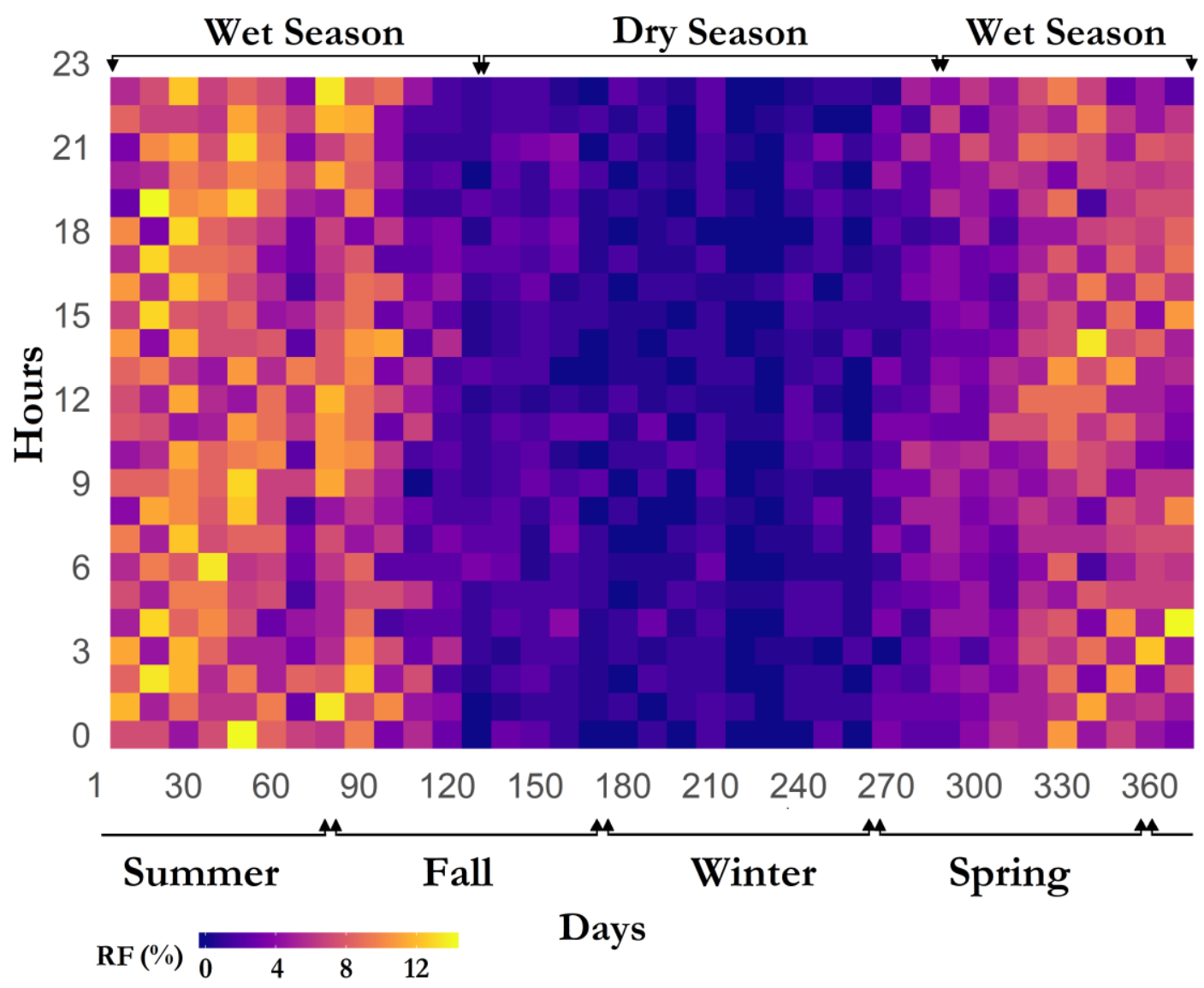

Figure 4 - Relative frequency of precipitation from 2003 to 2018 in Cuiabá, Mato Grosso, Brazil.

The weak rain occurred during more than $60 \%$ of all four seasons (Table 3). Only 7 Ppt events were classified as very strong rain throughout the study period: 2 in summer, 2 in fall, and 3 in spring.

There is a large increase in the availability of energy and humidity in the region during spring, which progressively intensifies the convection process, which may cause rain showers in the afternoon and evening (CPTEC/INPE, 2011). The strong rain events in winter are associated with incursions of cold southern fronts (CAVALCANTI and KOUSKY, 2009). In addition, there are influence of lines of instability from the Amazon due to the formation of a line of cumulus-nimbus that cause strong rains in the afternoon during spring and summer (ALCÂNTARA, 2011). 
Table 3 - Mean of number of Ppt events ( \pm 95\% confidence interval) of weak (WK), moderate (MO), strong (ST) and very strong (VST) rain events during the four seasons from 2003 to 2018 in Cuiabá, Mato Grosso, Brazil.

\begin{tabular}{ccccccccc}
\hline Season & Events & $\begin{array}{c}\text { WK } \\
(\mathbf{\%})\end{array}$ & Events & $\begin{array}{c}\text { MO } \\
(\mathbf{\%})\end{array}$ & Events & $\begin{array}{c}\text { SO } \\
(\mathbf{\%})\end{array}$ & Events & $\begin{array}{c}\text { VST } \\
(\%)\end{array}$ \\
\hline Summer & $35.1 \pm 3.6$ & 68.1 & $14.8 \pm 3.0$ & 28.8 & $1.5 \pm 0.7$ & 2.9 & $0.08 \pm 0.0$ & 0.2 \\
Fall & $11.8 \pm 1.9$ & 63.1 & $6.3 \pm 1.7$ & 34.0 & $0.4 \pm 0.2$ & 2.4 & $0.08 \pm 0.0$ & 0.4 \\
Winter & $3.8 \pm 0.7$ & 73.8 & $1.2 \pm 0.6$ & 24.6 & $0.08 \pm 0.0$ & 1.6 & $0.0 \pm 0.0$ & 0.0 \\
Spring & $24.0 \pm 3.0$ & 64.2 & $11.9 \pm 2.3$ & 31.9 & $1.3 \pm 0.5$ & 3.6 & $0.125 \pm 0.1$ & 0.3 \\
\hline
\end{tabular}

Weak and moderate rain was predominant in the region during all four seasons, spreading throughout the daytime and some peaks take place in the afternoon (Figure 5). In general, strong and very strong rain events occurred in the afternoon and evening. The peak of strong rain during the winter was recorded on August 25, 2009 as a result of the action of a trough between high and medium levels of the atmosphere, positioned between the south of the North, Midwest and Southeast, which provided support for the formation of a moisture convergence zone that reinforced Ppt events in the region (CPTEC/INPE, 2009).

$$
\text { Moderate } \triangle \text { Strong } \square \text { Very Strong } \square \text { Weak }
$$
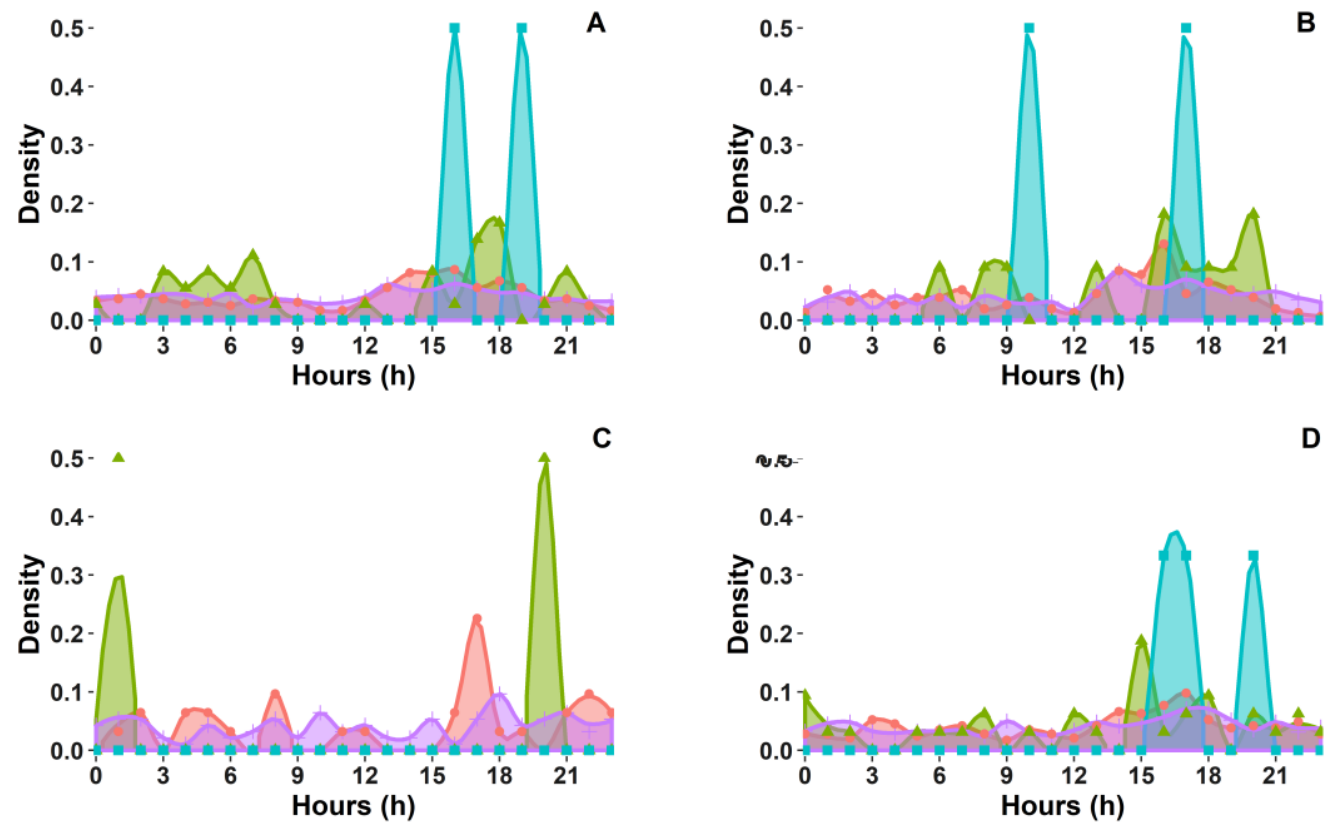

Figure 5 - Density distribution of precipitation per hour during the Summer (A), Fall (B), Winter (C) and Spring (D) from 2003 to 2018 in Cuiabá, Mato Grosso, Brazil.

The RF of Ppt during the summer was higher in the afternoon from 15:00 $\mathrm{h}(5.6 \%)$ and $16: 00 \mathrm{~h}(6.1 \%)$, and lower at $23: 00 \mathrm{~h}(3.2 \%)$ and $11: 00 \mathrm{~h}$ 
(2.9\%) (Figure 4). This temporal distribution of Ppt occurs due to the action of the Continental Equatorial Mass (mEc) characterized as a zone of low pressure and humidity concentration, which provides strong convective activities and formation of clouds with great vertical development (PEREIRA et al., 2013). Its genesis begins in low pressure areas in the Amazon region, due to the wide availability of humidity, latent heat and convergence of the Atlantic winds in the SE direction (NIMER, 1989). Episodes of SACZ and BH are quite recurrent during this period, inducing high rainfall in the region mainly in the afternoon due to the high convective activity.

The RF of Ppt during fall was higher in late afternoon between from $16: 00 \mathrm{~h}(5.8 \%)$ to $17: 00 \mathrm{~h}(6.1 \%)$, and lower near noon from 11:00 $\mathrm{h}$ and $12: 00 \mathrm{~h}(2.7 \%)$ (Figure 4). During fall, there is the influence of the Tropical Atlantic Anticyclone, which is related to the advanced of the Subtropical High pressure system into the continent. This system act in conjunction with the Amazonian Equatorial High pressure and operating as a center of subsidence inhibiting convection and favoring high temperatures and low humidity (SETTE, 2005).

The RF of Ppt during the winter was higher in the evening at 23:00 $\mathrm{h}$ (5.3\%) and early in the morning at 03:00 $\mathrm{h}(5.5 \%)$ and $05: 00 \mathrm{~h}(5.5 \%)$ and lower in the afternoon at $12: 00 \mathrm{~h}(2.9 \%), 13: 00 \mathrm{~h}(1.8 \%), 14: 00 \mathrm{~h}(2.4 \%)$, $15: 00 \mathrm{~h}(2.6 \%)$ (Figure 4$)$. This pattern of RF of Ppt during winter is a result of the incursion of cold fronts of polar origin, locally called "friagens", which cause Ppt events and temperature drop (MARENGO and NOBRE, 2009; BIUDES et al., 2012).

The RF of Ppt during the spring was higher in the afternoon at 16:00 $\mathrm{h}$ $(6.2 \%), 17: 00 \mathrm{~h}(6.8 \%)$ and $18: 00 \mathrm{~h}(6.0 \%)$, and lower near noon at 10:00 $\mathrm{h}$ $(3.1 \%), 11: 00 \mathrm{~h}(2.9 \%)$ and $12: 00 \mathrm{~h}(3.2 \%)$ (Figure 4$)$. Spring is a wintersummer transition season, when occurs an inversion in atmospheric circulatory patterns. The Subtropical High pressure system, which was acting into the continent, is weakened and replaced by the surface Low Pressure system, which further the convection and vertical moisture transport increasing cloudiness and beginning the wet season in the region (SETTE, 2005).

The results of this study differ from studies on the Southern Amazon region, which observed high $\mathrm{RF}$ of Ppt in the morning (summer and fall) and in the afternoon (winter and spring) (PEDREIRA JUNIOR et al., 2018). The RF of Ppt in a rainforest of the Amazon is high in the late afternoon and in the evening and low in the morning (COSTA et al., 2018). The higher RF of Ppt in Rondônia occurs in the afternoon and the lower ones occurs in the morning (SANTOS NETO et al., 2014).

\section{CONCLUSIONS}

The RF of Ppt in Cuiabá from 2003 to 2018 were more frequent in the late afternoon (summer, fall and spring) and early in the morning (winter). The RI more frequent (higher than $60 \%$ ) was low weak, followed by moderate and strong. Only 7 Ppt events with intensity higher than $50 \mathrm{~mm} \mathrm{~h}-1$ (summer, fall and spring) were recorded. 


\section{ACKNOWLEDGEMENTS}

The research was supported in part by Universidade Federal de Mato Grosso (UFMT), Programa de Pós-Graduação em Física Ambiental (PPGFA/IF/UFMT), Instituto Federal de Mato Grosso (IFMT), Universidade Federal do Amazonas (UFAM), Coordenação de Aperfeiçoamento de Pessoal de Nível Superior (CAPES), Conselho Nacional de Desenvolvimento Científico e Tecnológico (CNPq, code numbers 310879/2017-5 and 305761/2018-8; Edital Universal 01/2016, code number 407463/2016-0) e Fundação de Amparo à Pesquisa do Estado de Mato Grosso (FAPEMAT - PRONEM 2014, code number 561397/2014).

\section{REFERENCES}

ALCÂNTARA, C. R. Linha de Instabilidade da Amazônia: Estudo de Caso e Importância das Características do Perfil do Vento na sua Formação e Desenvolvimento. Ciência e Natura, p. 197-226, dez. 2011.

ALVES, L. M. Clima da região centro-oeste do Brasil. In: CAVALCANTI, I. F. D. A., et al. Tempo e Clima no Brasil. São Paulo: Oficina de Textos, 2009.

BECK, F.; BÁRDOSSY, A.; SEIDEL, J.; MÜLLER, T.; SANCHIS, E. F.; HAUSER, A. Statistical analysis of sub-daily precipitation extremes in Singapore. Journal of Hydrology. 337-358, 2015.

BIUDES, M. S.; NOGUEIRA, J. S.; DALMAGRO, H. J.; MACHADO, N.G.; DANELICHEN, V. H. M.; SOUZA, M. C. Mudança no microclima provocada pela conversão de uma floresta de cambará em pastagem no norte do Pantanal. Revista de Ciências Agro-Ambientais, 10(1): 61-68, 2012.

BROWN, V. M.; BLACK, A. W.; KEIM, B. D. Hourly rainfall climatology of Louisiana. Theoretical and Applied Climatology, 2018.

BURAUSKAITE-HARJU, A.; GRIMVALL, A.; ACHBERGER, C.; WALTHER, A.; CHEN, D. Characterizing and visualizing spatio-temporal patterns in hourly precipitation records. Theoretical and Applied Climatology. 109(3-4):333-343, 2012.

CAVALCANTI, I.F.A.; KOUSKY, V.E. Frentes frias sobre o Brasil. Tempo e Clima no Brasil. Oficina de Textos, 2009.

CECÍlio, R. A. et al. Avaliação de interpoladores para os parâmetros das equações de chuvas intensa no Espírito Santo. Revista Ambiente e Água, v. 4, n. 3, p. 82-92, 2009.

CHIARANDA, R.; RIZZI, N.E.; COLPINI, R.; SOARES, T.S.; SILVA, V.S.M. Análise da precipitação e da vazão da bacia do Rio Cuiabá. Revista Brasileira de Ciências Agrárias, v. 7, n. 1, p. 117-122, 2012.

COSTA, A. C. L.; DR. RODRIGUES, H. J. B.; SILVA JUNIOR, J. A.; NUNES, L. R. C.; MORAES, B. C.; COSTA E COSTA, A.; CUNHA,A. C.; MEIR, P.; DR. MALHI, Y. Variabilidade Horária, Diária e Sazonal da Frequência e Intensidade de Precipitação em uma Floresta Tropical Chuvosa na Amazônia Brasileira. Revista Brasileira de Geografia Física, [S.I.], v. 11, n. 4, p. 1290-1302, out. 2018. 
CPTEC/INPE - Centro de Previsão do Tempo e Estudos Climáticos, 2009. Disponível: http://tempo.cptec.inpe.br/boletimtecnico/pt. Acesso em: 30/06/2019.

CPTEC/INPE -Centro de Previsão do Tempo e Estudos Climáticos, 2011. Disponível: http://infoclima.cptec.inpe.br/ rinfo/progclima/set_2011.shtml. Acesso em :15/05/2019.

DALLACORT, R.; MARTINS, J. A.; INOUE, H. M.; FREITAS, P. S. L.; COLETTI, A. J. Distribuição das chuvas no município de Tangará da Serra, médio norte do Estado de Mato Grosso, Brasil. Acta Scientiarum Agronomy, v. 33, n. 2, p. 193200, 2011.

FU, S.; LI, D.; SUN, J.; SI, D.; LING, J.; TIAN, F. A 31-year trend of the hourly precipitation over South China and the underlying mechanisms. Atmosphere Science Letters 17(3):216-222, 2016.

GAO, L.; HUANG, J.; CHEN, X.; CHEN, Y.; LIU, M. Risk of extreme precipitation under non stationarity conditions during the second flood season in the Southeastern Coastal Region of China. Journal of Hydrometeorology18(3):669681, 2016.

GIRÃO, O.; CORRÊA, A. C. B. A contribuição da geomorfologia para o planejamento da ocupação de novas áreas. Revista de Geografia, v. 21, n. 2, 2004.

GRIMM, A. M. The El Niño Impact on the Summer Monsoon in Brazil: Regional Processes versus Remote Influences. Journal of Climate 16, 263-280, 2003.

GRIMM, A. M. Variabilidade Interanual do Clima do Brasil. In: CAVALCANTI, I. F. A.; FERREIRA, N.J.; SILVA, M. G. A. J.; DIAS, M. A. F. S. (Eds.). Tempo e Clima no Brasil. São Paulo: Oficina de Textos, 354-374, 2009.

JOSHI, S.; GARBRECHT, J.; BROWN, D. Observed Spatiotemporal Trends in Intense Precipitation Events across United States: Applications for Stochastic Weather Generation. Climate, 7, 36, 2019.

MACHADO, N. G; BIUDES, M. S; QUERINO, C. A. S; DANELICHEN, V. H. M.; VELASQUE, M. C. S. Seasonal and interannual pattern of meteorological variables in Cuiabá, Mato Grosso state, Brazil. Revista Brasileira de Geofísica, Vol. 33(3), 2015b.

MACHADO, N. G.; MEIRELLES, T.; DANELICHEN, V. H. M.; QUERINO, C. A. S.; BIUDES, M. S. Estimation of Rainfall by Neural Network Over a Neotropical Region. Revista Brasileira de Climatologia, v. 17, p. 44 - 54, $2015 a$.

MARCUZZO, F. F. N.; CARDOSO, M. R. D.; FARIA, T. G. Chuvas no cerrado da região centro-oeste do Brasil: Análise histórica e tendência futura. Revista eletrônica Ateliê Geográfico, Goiânia - GO, v. 6, n. 2, p. 112-130, 2012.

MARCUZZO, F. F. N.; MELO, D. C.R.; ROCHA, H. M. Distribuição espaçotemporal e sazonalidade das chuvas no estado do Mato Grosso. Revista Brasileira de Recursos Hídricos, Porto Alegre, v. 16, n. 4, p. 157-167, out./dez. 2011.

MARCUZZO, F. F. N.; ROCHA, M. H.; MELO, D. C. R. Mapeamento da precipitação pluviométrica no Bioma Cerrado do estado do Mato Grosso - doi 
10.5216/bgg. V31i2.16847. Boletim Goiano De Geografia, v. 31, n. 2, p. 83-97, 2011.

MARENGO, J. A.; B. LIEBMANN; V. E. KOUSKY; N. P. FILIZOLA; I. C. WAINER. Onset and end of the rainy season in the Brazilian Amazon basin. Journal of Climate, v. 14, p. 833 - 852. 2001.

MARENGO J. A.\& NOBRE C. A. Clima da Região Amazônica. In: CAVALCANTI IFA, FERREIRA NJ, SILVA MGAJ \& DIAS MAFS (Eds.). Tempo e Clima no Brasil. São Paulo: Oficina de Textos, 197-212, 2009.

MINUZZI, R. B.; SEDIYAMA, G. C. Influência da topografia na precipitação: uma análise estatística e via imagens de satélite. Congresso Brasileiro de Meteorologia, Fortaleza, 2004.

NOBRE, C. A.; OBREgón, G. O.; MARENGo, J. A.; FU, R.; POVEDA, G. Características do Clima Amazônico: Aspectos Principais. Amazonia and Global Change. Washington DC. Geophysical Monograph Series 186. p. 149-162. 2009.

NIMER E. 1989. Climatologia do Brasil. 2 ed., Rio de Janeiro, Brasil: Instituto Brasileiro de Geografia e Estatística, 421 pp.

PEDREIRA JUNIOR, A. L.; QUERINO, C. A. S.; QUERINO, J. K. A. S.; SANTOS, L. O. F.; MOURA, A. R. M.; MACHADO, N. G. et al. Variabilidade horária e intensidade sazonal da precipitação no município de Humaitá - AM. Revista Brasileira de Climatologia, v. 22, p. 463-475, 2018.

PEREIRA, G.; SILVA, M. E. S.; MORAES, E. C. M.; CARDOZO, F. S. Avaliação dos Dados de Precipitação Estimados pelo Satélite TRMM para o Brasil. Revista Brasileira de Recursos Hídricos, v. 18, n.3-Jul/Set 2013,139-148.

PINTO, L. I. C.; COSTA, M. H.; LIMA, F. Z.; DINIZ, L. M. F.; SEDIYAMA, G. C.; PRUSKI, F. F. Comparação de Produtos de Precipitação Para a América do Sul. Revista Brasileira de Meteorologia, v. 24, p. 461-477, 2009.

QUERINO, C. A. S.; BIUDES, M. S.; MACHADO, N. G.; QUERINO, J. K. A. S.; SANTOS NETO, L. A; da SILVA, M. J. G.; ARRUDA, P.; NOGUEIRA, J.; Balanço de ondas curtas sobre floresta sazonalmente alagável do Pantanal Mato-Grossense. Revista Brasileira de Climatologia, v. 20, p. 252-266, 2017.

RAMOS, H. C.; DALLACORT, R.; NEVES, S. M. A. S.; DALCHIAVON, F. C.; SANTI, A.; VIEIRA, F. F. Precipitação e temperatura do ar para o estado de Mato Grosso utilizando krigagem ordinária. Revista Brasileira de Climatologia, [S.I.], v. 20, ago. 2017.

SANTOS, L. O. F.; QUERINO, C. A. S. ; QUERINO, J. K. A. S. ; PEDREIRA JUNIOR, A. L. ; MOURA, A. R. M. ; MACHADO, N. G. ; BIUDES, M. S. Rainfall data validation estimated by GPM satellite on the Southern Amazon region. Revista Ambiente e Água, 2019.

SANTOS NETO, L. A.; MANIESI, V.; SILVA, M. J. G.; QUERINO, C. A. S.; LUCAS, E. W. M.; BRAGA, A. P.; ATAÍDE, K. R. P. Distribuição horária da precipitação em Porto Velho-RO no período de 1998 - 2013. Revista Brasileira de Climatologia, v.14, 2014.

SENTELHAS, P.C.; CRUCIANI, D.E.; PEREIRA, A.S.; VILLA NOVA, N.A. Distribuição Horária de Chuvas Intensas de Curta Duração: Um Subsídio ao 
Dimensionamento de Projetos de Drenagem Superficial. Revista Brasileira de Meteorologia, v. 13, n. 1, p. 45-52, 1998.

SETTE, D. M. Os climas do Cerrado do Centro-Oeste. Revista Brasileira de Climatologia. Dez., v. 1, n. 1, p. 29-42, 2005.

SILVA, F. A. M; ASSAD, E. D.; STEINKE, E. T.; MÜLLER, A. G. 2008. Clima do Bioma Cerrado.

SILVA, J, P, R.; REBOITA, M, S.; ESCOBAR, G, C, J. Caracterização da Zona de Convergência do Atlântico Sul em campos atmosféricos recentes. Revista Brasileira de Climatologia, [S.I.], v. 25, set. 2019. ISSN 2237-8642.

SPIEGEL, M.R. Estatística. São Paulo: McGraw-Hill do Brasil, 1972.

TRENBERTH, K. E.; ZHANG, Y. How often does it really rain? Bulletin of American Meteorological Society, 99(2), pp.289-298, 2017.

TRENBERTH, K. E.; ZHANG, Y.; GEHNE, M. Intermittency in precipitation: duration, frequency, intensity, and amounts using hourly data. Journal of Hydrometeorology 18(5):1393-1412, 2017.

WESTRA, S.; ALEXANDER, L. V.; ZWIERS, F. W. Global increasing trends in annual maximum daily precipitation. Journal of Climate, v.26, n.11, p. 39033918, 2013. 